\title{
Travel medicine resources for Canadian practitioners
}

\author{
Teitelbaum $\mathrm{P}^{1}$ on behalf of the Committee to Advise on Tropical Medicine and Travel (CATMAT)* \\ ${ }^{1}$ The Riverside Travel Medicine Clinic, Ottawa, ON \\ *Correspondence: CATMAT.Secretariat@phac-aspc.gc.ca
}

\begin{abstract}
Objective: To provide travel medicine practitioners with a comprehensive (though not exhaustive) list of resources. Resources that appear to be most frequently used by health professionals currently practising this specialty have been included.

Methods: Select members of TravelMed, an international e-mail discussion forum for travel medicine practitioners were informally canvassed and presented with a question regarding which travel medicine resources they find to be most useful. Their responses informed the development of this Statement. In addition, the opinions of experts in travel medicine were solicited to identify resources. The scope was international; however, particular attention was given to Canadian sources of information.
\end{abstract}

Results: Travel medicine resources are listed and organized into the following categories: Courses, conferences and local travel medicine groups; Books; Canadian recommendations; Handbooks; periodicals and reports; Journals; Internet medicine forums; Online subscription services; Outbreak reports and travel advisories; Sources of malaria recommendations; More useful websites; Travel medicine clinics in Canada and abroad; and Certification.

Conclusion: There are many Canadian and international resources available to inform Canadian travel medicine practitioners.

\section{Preamble}

The Committee to Advise on Tropical Medicine and Travel (CATMAT) provides the Public Health Agency of Canada with ongoing and timely medical, scientific and public health advice relating to tropical infectious disease and health risks associated with international travel. The Agency acknowledges that the advice and recommendations set out in this statement are based upon the best current available scientific knowledge and medical practices and is disseminating this document for information purposes to both travellers and the medical community caring for travellers.

Persons administering or using drugs, vaccines, or other products should also be aware of the contents of the product monograph(s) or other similarly approved standards or instructions for use. Recommendations for use and other information set out herein may differ from that set out in the product monograph(s) or other similarly approved standards or instructions for use by the licensed manufacturer(s). Manufacturers have sought approval and provided evidence as to the safety and efficacy of their products only when used in accordance with the product monographs or other similarly approved standards or instructions for use.

\section{Introduction}

The goal of this document is to provide both the novice and the experienced travel medicine practitioner with a comprehensive (though not exhaustive) list of resources. Resources that appear to be most used by health professionals currently practising this specialty have been included. Select members of TravelMed, an international e-mail discussion forum for travel medicine practitioners, were informally canvassed and presented 
with a question regarding which travel medicine resources they find to be the most useful. Their responses informed the development of this Statement. In addition, the opinions of experts in travel medicine were solicited to identify resources.

The scope was international; however, particular attention was paid to Canadian sources of information. These are often more accessible to Canadian practitioners and reflect practice in this country.

Travel and tropical medicine frequently overlap. The intent of this document is to focus on travel medicine. Tropical medicine resources are cited mainly when they regularly include travel medicine material.

\section{Categories of resource}

\section{Courses, conferences and local travel medicine groups}

\section{Canada}

- $\quad$ Alberta Association of Travel Health Professionals Symposium and General Meeting

- Annually in early summer in Canmore, Alberta

- Blue Travel Health Conference (Colloque Bleu) (in French)

$\circ \quad$ Annually in spring in Montréal, Quebec

- $\quad$ Comité consultatif québécois en santé des voyageurs, INSPQ online module (in French)

- Fondation du CHUM travel health conference (in French)

$\circ \quad$ Annually in early fall in Montréal, Quebec

- Manitoba Travel Health Network Annual Conference

- Annually in April in Winnipeg, Manitoba

- McGill University Tropical Medicine course

- Biennially in spring in Montréal, Quebec

- NOVA Travel Medicine Conference

- Annually in November in Victoria, British Columbia

International

- American Society of Tropical Medicine and Hygiene Annual Meeting

$\circ$ Annually in November in different cities in the United States

- $\quad$ Asia Pacific Travel Health Society Congress

$\circ \quad$ Biennially on even years

- $\quad$ Conference of the International Society of Travel Medicine

$\circ \quad$ Biennially on odd years in spring in different host cities

- International Society of Travel Medicine (ISTM) travel medicine review and update course

- An update and review of the body of knowledge for the practice of travel medicine and assistance in the preparation for the Certificate in Travel Health exam.

- List of additional international travel medicine conferences can be found at the International Society of Travel Medicine's website.

\section{Books}

Travel medicine

- Keystone JS, Freedman DO, Kozarsky PE, Connor BA, Northdruft HD. Travel medicine, $3^{\text {rd }}$ ed. Philadelphia (PA): Saunders Elsevier Inc.; 2013.

- Weiss EA. Wilderness and travel medicine: A comprehensive guide, $4^{\text {th }}$ ed. Seattle, (WA): The Mountaineers Books; 2012.

- Zuckerman JN. Principles and practice of travel medicine, $2^{\text {nd }}$ ed. Chichester, West Sussex: Wiley-Blackwell; 2013.

Vaccines

- $\quad$ Plotkin SA, Orenstein WA, Offit PA. Vaccines, $6^{\text {th }}$ ed. China: Saunders, Elsevier Inc.; 2013. 
- Zuckerman JN, Jong EC. Travelers' Vaccines, $2^{\text {nd }}$ ed. Shelton (CT): People's Medical Publishing House - USA; 2010.

Travellers' diarrhea

- $\quad$ Ericsson C, DuPont H, Steffen R. Travelers' diarrhea, $2^{\text {nd }}$ ed. Hamilton (ON): BC Decker Inc.; 2008.

Tropical disease

- Farrar J, Hotez PJ, Junghanss T, Kang G, Lalloo D, White N. Manson's tropical diseases, $23^{\text {rd }}$ ed. China: Saunders Elsevier Inc.; 2014.

- Guerrant RL, Walker DH, Weller PF. Tropical infectious diseases: Principles, pathogens and practice, $3^{\text {rd }}$ ed. Philadelphia (PA): Saunders Elsevier Inc.; 2011.

- Magill AJ, Ryan ET, Hill D, Solomon T. Hunter's tropical medicine and emerging infectious diseases, $9^{\text {th }}$ ed. China: Saunders Elsevier Inc.; 2013.

- Schwartz E. Tropical diseases in travelers. Singapore: Blackwell Publishing; 2009.

Other

- $\quad$ Auerbach PS. Wilderness medicine, $6^{\text {th }}$ ed. Philadelphia (PA): Mosby Elsevier Inc.; 2012.

- Heymann DL. Control of communicable diseases manual, $20^{\text {th }}$ ed. Washington (DC): American Public Health Association; 2014.

- All travel health professionals should have access to a good atlas. Ideally, an atlas will show the states/provinces in most countries, since many malaria recommendations name these specifically. Topography should also be shown so that altitude information is obtainable.

\section{Canadian recommendations}

- $\quad$ Committee to Advise on Tropical Medicine and Travel (CATMAT): The external advisory committee of the Public Health Agency of Canada develops recommendation statements on a wide array of travel medicine topics.

- Canadian Immunization Guide: Developed by the Public Health Agency of Canada, using National Advisory Committee on Immunization (NACl) and Committee to Advise on Tropical Medicine and Travel (CATMAT) recommendations and guidelines for all vaccines licensed for use in Canada. It deals comprehensively with problematic situations such as immunizing immunosuppressed travellers.

\section{Handbooks, periodicals and reports}

- $\quad$ Canada Communicable Disease Report (CCDR): Travel medicine articles, including CATMAT recommendations appear fairly often in this publication.

- $\quad$ CDC Health Information for International Travel (commonly called the "Yellow book"): Published by the Centers for Disease Control and Prevention (CDC) in the United States.

- International Travel and Health: Published by the World Health Organization (WHO).

5. Journals

Journals devoted to travel medicine

- Journal of Travel Medicine

- $\quad$ Travel Medicine and Infectious Disease

Journals that sometimes include travel medicine content

- $\quad$ The American Journal of Tropical Medicine and Hygiene

- British Medical Journal

- $\quad$ Clinical Infectious Diseases

- Emerging Infectious Diseases

- Infectious Disease Clinics of North America

- Journal of Infection

- The Journal of Infectious Diseases 
- $\quad$ The Lancet

- The Lancet Infectious Diseases

- Malaria Journal

- Morbidity and Mortality Weekly Report

- Vaccine

Other major medical journals will occasionally include travel medicine content (e.g., NEJM, JAMA, etc.).

\section{Internet travel medicine forums}

- TravelMed: International travel medicine e-mail discussion forum, open to members of the International Society of Travel Medicine.

\section{Online subscription services}

These programs/services provide detailed assistance for any itinerary. The user inputs itinerary and traveller information. The program displays its recommendations regarding immunizations, malaria prophylaxis and advice. Generally, these resources can be very helpful for less-experienced practitioners.

- $\quad$ Gideon: Primarily a tropical and infectious disease diagnostic program but includes detailed epidemiologic information on travel-related diseases. US $\$ 995^{*}$ per year for individual subscription.

- Sitata: An online service for travellers and travel medicine clinics, US $\$ 540^{*}$ per year.

- $\quad$ TravaxShoreland: A popular source of travel medicine information, US $\$ 895^{*}$ per year for single clinic license.

- $\quad$ TRAVAX (United Kingdom): Price available on request of application to TRAVAX.

- $\quad$ Tropimed: US $\$ 219$ per year (at time of publication).

\section{Outbreak reports and travel advisories}

It is highly recommended that practitioners stay current regarding disease outbreaks of importance to travellers. The following sources provide up-to-date information that can be used in this regard.

- $\quad$ Disease Outbreak News: WHO, Global Alert and Response.

- GeoSentinel: A worldwide data collection and communication network associated with the International Society of Travel Medicine and the US Centers for Disease Control and Prevention.

- Government of Canada Travel News and Advisories - highlights the latest updates on threats and conditions considered unsafe for Canadians around the world.

- Government of Canada Travel health Advisories - outlines potential risks to Canadian travellers and to the Canadian public, and recommends measures that can be taken to reduce these risks.

- Global Polio Eradication Initiative: Polio updates, WHO, UNICEF, Rotary International and CDC.

- Healthmap: A map-based reporting system for outbreaks.

- Meningitis Vaccine Project: Meningococcal meningitis updates, WHO.

- ProMED: At this time perhaps the most frequently used disease outbreak e-mail service. Past outbreak reports are available on the ProMED website. These reports are timely, though may not always be confirmed.

- Weekly Epidemiological Record: WHO, outbreak reports.

- Several of the online subscription services listed above provide regular disease outbreak and security reports. 
9. Sources of malaria recommendations

Links to Canadian guidelines are presented here. Included as well are those of several other jurisdictions. Recommendations regarding the need for chemoprophylaxis can vary widely. Familiarity with a broad set of national guidelines can provide practitioners with a wider perspective for developing recommendations and advice, in particular for itineraries associated with a "low" risk of malaria.

Canadian

- Canada, 2014: Travellers, Committee to Advise on Tropical Medicine and Travel.

- Québec, 2013: Guide d'intervention en santé-voyage, published by the Institut national de santé publique du Québec.

European

- France, 2014: Recommandations sanitaires pour les voyageurs, 2014 (available in French only)

- Germany, 2015: Deutsche Gesellschaft für Tropenmedizin und Internationale Gesundheit (DTG). Empfehlungen zur Malariavorbeugung (available in German only)

- Italy, 2014: New Italian Guidelines for malaria prophylaxis in travellers to endemic areas and Indicazioni per La Profilassi Antimalarica nei viaggiatori in area endemic (available in Italian only)

- Sweden, 2013: Rekommendationer för malariaprofylax (available in Swedish only)

- Switzerland, 2014: Comité d'experts en médecine des voyages (Suisse)

- Conseils médicaux aux voyageurs (available in French and German only) and Confédération suisse. Office fédéral de la santé publique OFSP.

- Paludisme (Malaria) (available in French and German only)

- United Kingdom, 2014: Malaria Prevention Guidelines for travellers from the UK

International

- $\quad$ IAMAT 2014 - World Malaria Risk Chart, International Association for Medical Assistance to Travellers (IAMAT).

- World Health Organization: International Travel and Health (ITH).

United States

- Centers for Disease Control and Prevention: Malaria and Travelers

10. More useful websites

- Bulletin épidemiologique hebdomaire, French Institute for Public Health Surveillance (France).

- $\quad$ Canadian Malaria Network: Timely medical access to artesunate or quinine for the treatment of malaria.

- CanTravNet: Canadian travel medicine clinic surveillance network.

- Health Canada's ship inspection program: Provides inspection scores for cruise ships.

- Malaria atlas project: Disseminates free, accurate and up-to-date information on malaria and associated topics, organized on a geographical basis.

- National Reference Centre for Parasitology: Reference diagnostic service in serology for parasitic diseases.

- National Travel Health Network and Centre (United Kingdom).

- Storage and Handling of Immunizing Agents, Canadian Immunization Guide.

- The BCG World Atlas - www.bcgatlas.org: A Database of Global BCG Vaccination Policies and Practices.

- TST/IGRA interpreter: This tool estimates the risk of active tuberculosis for an adult with a tuberculin skin test reaction of $\geq 5 \mathrm{~mm}$, based on his/her clinical profile.

- US cruise ship inspection ratings: provides inspection scores for cruise ships. 


\section{Travel medicine clinics in Canada and abroad}

- International Association for Medical Assistance to Travel.

- Online Clinic Directory, International Society of Travel Medicine.

- Tropical and Travel Medicine Consultant Directory, American Society of Tropical Medicine and Hygiene.

- Yellow Fever Vaccination Centres in Canada.

\section{Certification}

- The International Society of Travel Medicine holds at least one Certificate of Knowledge examination each year. It is held in conjunction with the biannual conference and regional meetings of the ISTM. Successful candidates are awarded a certificate attesting to proficiency in travel medicine.

- American Society of Tropical Medicine and Hygiene holds an examination for the Certificate of Knowledge in Clinical Tropical Medicine and Traveler's Health.

- Royal College of Physicians and Surgeons of Glasgow offers a diploma in travel medicine.

\section{Conclusion}

There are many Canadian and international resources available to inform Canadian travel medicine practitioners.

\section{Acknowledgements}

This Statement was prepared by Dr. P. Teitelbaum and approved by CATMAT. CATMAT acknowledges and appreciates the contribution of Kelsie Jagt, Jennifer Cutler and Maggie Bryson.

CATMAT Members: McCarthy A (Chairperson), Boggild A, Brophy J, Bui C, Crockett M, Greenaway C, Libman M, Teitelbaum P, Vaughan S.

Liaison Members: Gershman M (US Centres for Disease Control and Prevention), Pernica J (Association of Medical Microbiology and Infectious Disease Canada).

Ex-officio Members: Marion M (Canadian Forces Health Services Centre, Department of National Defence), McDonald P (Division of Anti-Infective Drugs, Health Canada), Schofield S (Directorate of Force Health Protection, Department of National Defence) and Tepper M (Directorate of Force Health Protection, Department of National Defence).

\section{Conflict of interest}

None

\section{Funding}

This work was support by the Public Health Agency of Canada. 